\title{
Plant Population and Nitrogen Fertilization for Subsurface Drip-irrigated Onion
}

\author{
Clinton C. Shock, ${ }^{1}$ Erik B. G. Feibert, ${ }^{2}$ and Lamont D. Saunders ${ }^{3}$ \\ Malheur Experiment Station, Oregon State University, 595 Onion Avenue, \\ Ontario, OR 97914
}

\section{Additional index words. Allium cepa, $\mathrm{N}$ uptake, $\mathrm{N}$ mineralization}

\begin{abstract}
Onion (Allium cepa L.) production in the Treasure Valley of eastern Oregon and southwestern Idaho has been based on furrow irrigation with $318 \mathrm{~kg}^{\cdot h a^{-1}} \mathrm{~N}$ fertilizer and average yields of $70 \mathrm{Mg} \mathrm{ha}^{-1}$, but these practices have been implicated in nitrate contamination of groundwater. Drip irrigation, introduced in the early $1990 \mathrm{~s}$, has several advantages, including reduced leaching losses. Since onion plant populations and $\mathbf{N}$ fertilizer rates can affect economic returns, studies were conducted in 1999, 2000, and 2001 to determine optimum plant populations and $\mathbf{N}$ fertilizer rates for subsurface drip-irrigated onion. Long-day onion ('Vision') was subjected to a combination of seven nitrogen fertilization rates ( 0 to $336 \mathrm{~kg} \mathrm{ha}^{-1}$ in 56-kg increments applied between late May and early July) and four plant populations $(185,250,300$, and 370 thousand plants/ha). Onion was grown on silt loam in two double rows spaced $0.56 \mathrm{~m}$ apart on $1.1 \mathrm{~m}$ beds with a drip tape buried $13 \mathrm{~cm}$ deep in the bed center. Soil water potential was maintained nearly constant at $-20 \mathrm{kPa}$ by automated irrigations based on soil water potential measurements at a $0.2-m$ depth. Onion bulbs were evaluated for yield and grade after $\mathbf{7 0}$ days of storage. Onion yield and grade were highly responsive to plant population. Onion marketable yield increased, and bulb diameter decreased with increasing plant population. Within the range of plant populations tested, gross returns were not always responsive to plant population. Returns were increased by the increase in marketable yield obtained with higher plant population, but higher plant population also reduced the production of the largest sized bulbs which had the

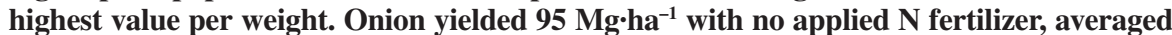
over plant populations and years. Onion yield and grade were not responsive to $\mathrm{N}$ fertilizer rate or interaction of $\mathbf{N}$ fertilizer rate with plant population. Preplant soil available $\mathbf{N}, \mathbf{N}$ mineralization, and $\mathrm{N}$ in irrigation water all contributed $\mathrm{N}$ to the crop. Onion $\mathrm{N}$ uptake did not increase with increasing $\mathbf{N}$ fertilizer rate.
\end{abstract}

The Treasure Valley of eastern Oregon and southwestern Idaho annually produces 9000 ha of sweet spanish onion, classified as long-day and medium-to-long storage (Shock et al., 2000b). Treasure Valley onion is generally grown on silt loam soils and have traditionally been fertilized with an average of $318 \mathrm{~kg} \cdot \mathrm{ha}^{-1}$ nitrogen with some use as high as $448 \mathrm{~kg} \cdot \mathrm{ha}^{-1}$ (Jensen and Simko, 1991). Onion is marketed starting at harvest in August and out of storage through April, so maintaining quality during storage is indispensable. Onion growers in the Treasure Valley have targeted the larger onion size classes, jumbo and colossal. Plant population has a large influence on onion bulb size at harvest because plant competition and lack of available space can restrict bulb enlargement. Previous research investigating the optimum plant population for furrow-irrigated onion

Received for publication 30 Dec. 2002. Accepted for publication 12 Feb. 2004. Oregon State Univ. technical paper no. 11972. We thank the Oregon Watershed Enhancement Board,EPA 319 funds, and the Idaho-Eastern Oregon Onion Commission for financial support for this study. Use of trade names does not imply endorsement of the products named or criticism of similar ones not named.

${ }^{1}$ Professor and superintendent; e-mail Clinton. Shock@oregonstate.edu.

${ }^{2}$ Senior faculty research assistant.

${ }^{3}$ Biological sciences research technician. in the Treasure Valley found gross returns to be maximized by plant populations ranging from 309,000 to 514,000 plants/ha (Shock et al., 1990). In that study, jumbo was the largest bulb size class measured. By the mid-1980s Treasure Valley packers were commonly marketing colossal bulbs [>102 mm (>4 inches)] and by the mid-1990s Treasure Valley packers started marketing a new onion bulb size class [super colossals, bulb diameter $>108 \mathrm{~mm}$ ( $>4.25$ inches)].

The use of drip irrigation has been increasing for onion production in the Treasure Valley. The economic optimum plant population could be different for onions under drip irrigation than under furrow irrigation. A reevaluation of the influence of plant population on bulb size was needed. We hypothesized that due to the premiums paid for the newer, larger bulb size classes, financial returns would be better at lower plant populations than found in our previous work in the late 1980s.

When investigating onion yield response to plant population, the N supply to the crop must be sufficient for optimum yield. The optimum $\mathrm{N}$ supply could be different and lower for drip-irrigated onions than for furrow-irrigated onions. With drip irrigation, N leaching could be lower, because drip irrigation allows for relatively frequent small irrigations, thus maintaining the soil water potential relatively constant compared with furrow irrigation, without a large leaching fraction. We also hypothesized that with carefully controlled drip irrigation, onion yield response to $\mathrm{N}$ fertilizer would be small or nonexistent in typical Treasure Valley crop production soils. In previous trials, furrow-irrigated onions had shown limited response to N fertilization (Shock et al., 1991; Miller et al., 1992).

In 1989 northern Malheur County was declared a groundwater management area due to groundwater nitrate contamination (Anon., 1991). The groundwater contamination had been linked, at least in part, to furrow-irrigated onion (Bruch, 1986). Growers typically use $1130 \mathrm{~mm}$ of irrigation water for furrow-irrigated onion (Jensen and Simko, 1991), yet onion evapotranspiration is in the range of 790 $\mathrm{mm} \cdot$ year $^{-1}$. We had compared drip and sprinkler to furrow irrigation systems for onion production, starting in 1992 (Feibert et al. 1995), attempting to introduce practical alternatives that would maintain onion productivity while using less water. Hence, these alternatives would potentially have less risk of nitrate leaching. In work immediately preceding the present study, onion yield and grade were shown to be very sensitive to the drip-irrigation criterion: a soil water potential criterion of $-20 \mathrm{kPa}$ was recommended based on yield and grade without extra risk of bulb decomposition in storage (Shock et al, 2000a).

The objectives of this research were to investigate onion yield response to plant population and to test the hypothesis that the $\mathrm{N}$ fertilizer requirements of onions under drip irrigation in the Treasure Valley could be low or nonexistent. Our hypothesis was directly in contradiction to grower assumptions. Growers observed very high yields under drip irrigation. Seeing the entire top of the onion bed wet from the drip tape, they imagined that more onions could be planted perhectare. Furthermore, growers reasoned the greater yields would require increased $\mathrm{N}$ fertilizer.

\section{Materials and Methods}

The trials were conducted in 1999, 2000, and 2001 at the MalheurExperiment Station, Ontario, Ore., on Owyhee silt loam (coarse-silty, mixed, mesic, Xerollic Camborthids) previously planted to wheat (Triticum aestivum L.). Fertilizer was applied in the fall before each trial based on soil tests to correct nutrient deficiencies other than N. In Fall 1998, $22 \mathrm{~kg} \cdot \mathrm{ha}^{-1} \mathrm{~N}$ and $44 \mathrm{~kg} \cdot \mathrm{ha}^{-1}$ $\mathrm{P}$ were broadcast. In Fall 1999, $22 \mathrm{~kg} \cdot \mathrm{ha}^{-1} \mathrm{~N}$, $44 \mathrm{~kg} \cdot \mathrm{ha}^{-1} \mathrm{P}$, and $1 \mathrm{~kg} \cdot \mathrm{ha}^{-1} \mathrm{~B}$ were broadcast. In Fall 2000, $98 \mathrm{~kg} \cdot \mathrm{ha}^{-1} \mathrm{P}, 62 \mathrm{~kg} \cdot \mathrm{ha}^{-1} \mathrm{~K}, 168$ $\mathrm{kg} \cdot \mathrm{ha}^{-1} \mathrm{~S}, 31 \mathrm{~kg} \cdot \mathrm{ha}^{-1} \mathrm{Mg}, 11 \mathrm{~kg} \cdot \mathrm{ha}^{-1} \mathrm{Zn}$, and 6 $\mathrm{kg} \cdot \mathrm{ha}^{-1} \mathrm{Cu}$ were broadcast. Nitrogen was only added because of limitations in the commercial $\mathrm{P}$ fertilizer composition 2 years. An analysis of a composite soil sample of the top $30 \mathrm{~cm}$ taken in mid-May each year showed $1.4 \%, 2.3 \%$, and $0.6 \%$ organic matter and a $\mathrm{pH}$ of $7.3,7.2$, and 7.9 in 1999, 2000, and 2001, respectively. For the 2000 and 2001 trials the fields were plowed, groundhogged twice, fumigated with Telone C17 at $225 \mathrm{~L} \cdot \mathrm{ha}^{-1}$ and bedded in the fall preceding the trial. For the 1999 crop, the fall field prepara- 
Table 1. Average price of onions $(\$ / \mathrm{Mg})$ paid to the grower from the beginning of the marketing season in early August through January from 1992 through the respective trial year.

\begin{tabular}{lcccc}
\hline & \multicolumn{4}{c}{ Onion size class } \\
\cline { 2 - 4 } Year & Medium & Jumbo & Colossal & Super colossal \\
\hline 1999 & 61.41 & 122.16 & 201.21 & 242.55 \\
2000 & 59.39 & 119.56 & 193.70 & 236.38 \\
2001 & 53.54 & 113.60 & 184.82 & 23 \\
\hline
\end{tabular}

tion was the same but the field was bedded in the spring before planting on 24 Mar.

Onion ('Vision', Seminis Inc., Oxnard, Calif.) was planted in two double rows per 1.1-m bed in late March each year. The onion double rows were spaced $0.56 \mathrm{~m}$ apart. Each double row consisted of two onion rows spaced $6 \mathrm{~cm}$ apart. Onion was planted at 519,000 seeds/ha. At the same time as planting, one drip tape (Nelson Pathfinder; Nelson Irrigation Corp., Walla Walla, Wash.) was installed in each bed at a $13-\mathrm{cm}$ depth between the two double rows. The tape had emitters spaced $30 \mathrm{~cm}$ apart and an emitter flow rate of $0.50 \mathrm{~L} \cdot \mathrm{h}^{-1}$. The field was sprinkler irrigated until seedling emergence.

Nitrogen treatments were the main plots and were replicated three times each year. Nitrogen treatments were arranged in a randomized complete block design. Plant populations were split plots within each $\mathrm{N}$ plot. The plant populations $(185,000,247,000,309,000$, and 370,000 plants/ha) were achieved by hand thinning in mid-May. Individual population plots were two beds wide and $15 \mathrm{~m}$ long. The seven $\mathrm{N}$ rates ranged from 0 to $336 \mathrm{~kg} \cdot \mathrm{ha}^{-1}(0,56,112,168$, 224,280 , and $336 \mathrm{~kg} \cdot \mathrm{ha}^{-1}$ ) within the range of grower practices. The nitrogen for each treatment was split into five equal amounts and applied every $10 \mathrm{~d}$ from mid-May to early July. The N fertilizer was applied through the drip tape as urea-ammonium nitrate solution $(32 \% \mathrm{~N}$ by weight) using a venturi injector (Mazzei injector model 287; Mazzei Injector Corp., Bakersfield, Calif.) installed in each plot.

The soil was sampled in $0.3-\mathrm{m}$ increments down to $0.6 \mathrm{~m}$ in each replication in mid-May before the application of the $\mathrm{N}$ treatments. The soil was also sampled after harvest. Each post harvest soil sample was a composite of 20 cores in each 309,000 plants/ha subplot. Soil sample cores were taken systematically from the furrow bottoms all the way across the beds to represent the range of nitrate variability. All soil samples were analyzed for nitrate and ammonium. The nitrate and ammonium were extracted using $2 \mathrm{M}$ $\mathrm{KCl}$ and analyzed using the cadmium reduction method for the nitrate and the exchangeable ammonium method (Carlson, 1978, 1986).

The mid-May soil samples taken from each replicate for the top $0.6 \mathrm{~m}$ of soil in $0.3-\mathrm{m}$ increments were used for $\mathrm{N}$ mineralization estimates. Nitrogen mineralization was estimated by available N difference and by anaerobic incubation at $40^{\circ} \mathrm{C}$ for $7 \mathrm{~d}$ (Waring and Bremner, 1964). The well water used for irrigation was sampled and analyzed for $\mathrm{NO}_{3}-\mathrm{N}$ and $\mathrm{NH}_{4}-\mathrm{N}$ once in 2000 and twice in 2001. The well water sampled had an average $\mathrm{NO}_{3}-\mathrm{N}$ and $\mathrm{NH}_{4}-\mathrm{N}$ concentration of $8.3 \mathrm{ppm}$ and $2.1 \mathrm{ppm}$ in 2000 and $10.4 \mathrm{ppm}$ and 1 ppm in 2001, respectively. Nitrogen contribution from irrigation was calculated to be 0.034 and $0.042 \mathrm{~kg} \cdot \mathrm{ha}^{-1} \cdot \mathrm{mm}^{-1}$ of water applied in 2000 and 2001, respectively. The analyses in 2002 were similar to the values in prior years, so they were used to make estimates for 1999.

In late August 2000 and 2001, 10 onion plants adjoining the harvest area from each subplot were taken for analysis of total N content. The leaves were weighed, dried, weighed, and ground. The bulbs were weighed and shredded. A shredded bulb subsample was weighed, dried, weighed, and ground. The ground leaf and bulb samples were analyzed for total Kjeldahl $\mathrm{N}$ concentration. Total N uptake for 2000 and 2001 was calculated based on bulb yield, bulb and leaf fresh weight and dry weights, and tissue $\mathrm{N}$ concentration. The crop $\mathrm{N}$ uptake for 1999 was estimated using the average tissue $\mathrm{N}$ content for the corresponding $\mathrm{N}$ treatments from 2000 and 2001. An available $\mathrm{N}$ difference was calculated by subtracting the total N supply (mid-May soil N plus fertilizer N plus Nin irrigation water, and ignoring $\mathrm{N}$ mineralization) from the post-harvest soil-available N plus crop N uptake. The N difference represents apparent available $\mathrm{N}$ gained or lost from the top $0.6 \mathrm{~m}$ of soil.

Soil water potential (SWP) was measured with one granular matrix sensor (GMS, Watermark Soil Moisture Sensors model 200SS; Irrometer Co. Inc., Riverside, Calif.) at 0.2-m depth, below an onion row in each split plot, so that there were 4 sensors in each main plot at $0.2-\mathrm{m}$ depth, 84 in all. In addition, each main plot had a GMS installed at 0.46-m depth below an onion row in the 309,000 plants/ha split plot (21 in all) (Shock, 2003). Sensors were calibrated to SWP (Shock et al. 1998a). The GMS were connected to a datalogger (CR 10; Campbell Scientific, Logan, Utah) via multiplexers (AM 410 multiplexer, Campbell Scientific). The datalogger was programmed to read the GMS every $3 \mathrm{~h}$ and, if the average of all sensors at $0.2 \mathrm{~m}$ depth was less than -20 $\mathrm{kPa}$, it would irrigate the field by applying 1.5 $\mathrm{mm}$ of water as has been previously shown to optimize onion yield at Ontario, Ore. (Shock et al., 2000a). The irrigations were controlled by the datalogger actuating a solenoid valve. The pressure in the drip lines was maintained at $69 \mathrm{kPa}$ by pressure regulators in each main plot. The automated drip-irrigation system was started in mid May. The amount of water applied to the field was recorded daily at $8 \mathrm{AM}$ from a water meter installed downstream of the solenoid valve. The total amount of water applied included sprinkler irrigations applied after emergence, water applied through the drip-irrigation system, plus the small amounts of precipitation each year from emergence through the final irrigation.

Onion evapotranspiration (ET) was calculated with a modified Penman equation (Wright, 1982) using data collected at the Malheur Experiment Station by an AgriMet weather station (U.S. Bureau of Reclamation, Boise, Idaho). Onion ET was estimated and recorded from crop emergence in mid-April until the final irrigation on 31 Aug. each year. Water application efficiency was calculated as the ratio of Et to the amount of irrigation plus precipitation.

In mid-September the onions were lifted to field cure. After ten days, onions in the central $12 \mathrm{~m}$ of the middle two double rows in each subplot were topped, bagged, and placed into storage. The automated storage was managed to gradually cool the onions to $1^{\circ} \mathrm{C}$ by ventilating with outdoor air. The onions were graded in mid-December. Bulbs were separated according to quality: bulbs without blemishes (No. 1s), split bulbs (No. 2s), and diseased bulbs. The No. 1 bulbs were graded mechanically (Kerian Speed Sizer, Kerian Machines, Inc., Grafton, N.D.) according to local custom diameter size classes: small $(<57 \mathrm{~mm})$, medium (57 to 76 $\mathrm{mm}$ ), jumbo (76 to $102 \mathrm{~mm})$, colossal (102 to $108 \mathrm{~mm}$ ), and supercolossal (>108 mm). Counts of supercolossal bulbs were made during grading. Onions were not graded into the supercolossal category in 1999. Marketable onions were considered perfect bulbs in the medium, jumbo, colossal, and supercolossal size classes. Bulbs from all subplots were counted during grading in order to determine the plant population at harvest. Onion yield and quality responses to plant population were based on the plant populations at harvest.

Gross economic returns for each year were calculated by crediting each marketable onion class with the price paid to the grower. Due to highly variable prices over time, the prices for each onion size class were averaged over the marketing season from early August through January and averaged over the years 1992 through the respective trial year. Onion prices (Table 1) were obtained from the USDA Agricultural Marketing Service, Idaho Falls, Idaho, and reflect adjustments for packing and shipping costs.

Data was subjected to analysis of variance (ANOVA) using the general linear model ANOVA procedure (NCSS, Kaysville, Utah) and regression analysis using the response surface regression procedure. The ANOVA had N rates as the main effect and plant population as split plots. The ANOVA showed no significant interaction effects of N rate and plant population, so $\mathrm{N}$ rate and plant population were submitted to regression analysis separately. The plant populations for maximum gross return responses were calculated from the first derivative of the regression equation using the formula $x=-\mathrm{b} / 2 \mathrm{c}$, where $x$ is the plant population and $\mathrm{b}$ and $\mathrm{c}$ are the regression equation coefficients for the first and second order terms, respectively, of the response equation $y=\mathrm{a}+\mathrm{b} x+\mathrm{c} x^{2}$.

\section{Results and Discussion}

Effect of plant population. There were no significant interactions between plant population and $\mathrm{N}$ rate and minimal responses to $\mathrm{N}$ rate, consequently the plant population data was averaged over $\mathrm{N}$ rates. Colossal and supercolossal onion yield decreased with increasing plant population, whereas medium, jumbo, and total marketable onion yield increased 
(Figs. 1, 2, and 3). In 1999, when grading did not include supercolossal onions, gross returns increased with increasing plant population and reached a maximum at 371,000 plants/ha (Fig. 4). Colossal and supercolossal bulbs are favored by low plant populations and less plant competition. In 2000, gross returns increased with increasing plant population and reached a maximum at 266,000 plants/ha. In 2001, gross returns were not responsive to the range of plant populations tested. When supercolossal onions are considered, the plant population that maximizes gross returns is lower or, as in 2001, the monetary response might disappear. In 2001, the increase in gross returns, resulting from the increase in marketable yield with increasing plant population, was offset by the decrease in supercolossal onions which have the highest value per weight (Table 1). The plant populations maximizing gross returns in 2000 and 2001 were substantially lower than the range of 309,000 to 514,000 plants/ha found to maximize gross returns previously (Shock et al., 1990), when colossal and supercolossal bulbs were neither measured nor as important in onion marketing. The introduction of supercolossal onions shifts the range of plant populations that result in maximum gross returns toward lower plant populations compared to 1999 when the largest size class measured was colossal bulbs. It was difficult to predict the optimum onion plant population in any year due to price variability. Onion prices vary by size class depending

Fig. 1. Onion yield response to plant population in 1999 over all $\mathrm{N}$ rates. on availability, which depends on weather in several production areas.

Onion response to fertilizer $N$ rate. There was no significant effect of $\mathrm{N}$ rate on onion yield (Fig. 5), grade, or gross returns. The initial residual soil nitrate and ammonium, nitrate and ammonium in the irrigation water, and probable mineralized $\mathrm{N}$, combined to provide sufficient $\mathrm{N}$ to meet the crop $\mathrm{N}$ uptake (Table 2). These results agree with our hypothesis of the low $\mathrm{N}$ fertilizer requirements of onion in Treasure Valley production fields. Previous research at the Malheur Experiment Station investigating $\mathrm{N}$ rates for furrow-irrigated onion found no response of onion yield to $\mathrm{N}$ fertilizer in 3 out of 4 site years (Miller et al., 1992; Shock et al., 1991). In the current trials, the marketable yield for drip-irrigated onion not receiving $\mathrm{N}$ fertilizer any time during the growing season averaged 92, 95, and $99 \mathrm{Mg} \cdot \mathrm{ha}^{-1}$ in 1999, 2000, and 2001, respectively. These marketable yields are substantially higher than the average county total yields of 75, 67, and $69 \mathrm{Mg} \cdot \mathrm{ha}^{-1}$ in 1999 , 2000, and 2001, respectively. Low N needs for drip-irrigated onion are consistent with full size commercial demonstrations recently completed (Shock and Klauzer, 2003).

The fields used in these trials have a history of moderate $\mathrm{N}$ inputs and are representative of Treasure Valley soils. The fields had 1 year of lightly fertilized sprinkler-irrigated potato (Solanum tuberosum L.) and 4 years of furrowirrigated wheat in the 5 years previous to the trial. Each wheat crop received $\mathrm{N}$ at $168 \mathrm{~kg} \cdot \mathrm{ha}^{-1}$. A survey of local grower $\mathrm{N}$ use found wheat to be fertilized with an average of $152 \mathrm{~kg} \cdot \mathrm{ha}^{-1}$ of N (Jensen and Simko, 1991). Local growers do not plant wheat in 4 successive years, but rotate other crops with higher $\mathrm{N}$ inputs, so the fields used for these trials had a $\mathrm{N}$ fertilization history equal to or less than what is typical. The average amount of $\mathrm{N}$ removed by harvested wheat averages $236 \mathrm{~kg} \cdot \mathrm{ha}^{-1} \cdot \mathrm{year}^{-1}$ (Shock and Stieber, 1991). In a study of Treasure Valley soils, the preplant soil available $\mathrm{N}$ in the top 0.6 $\mathrm{m}$, in seven fields following wheat, averaged $145 \mathrm{~kg} \cdot \mathrm{ha}^{-1}$ (Stieber et al., 1995), consistent with the levels found in our fields.

Nitrogen differences and losses. Where no $\mathrm{N}$ fertilizer was used on onion in the current trials, there was an estimated available $\mathrm{N}$ accounting surplus of 167,170 , and $70 \mathrm{~kg} \cdot \mathrm{ha}^{-1}$ in 1999, 2000, and 2001 respectively. These accounting surpluses are apparently from $\mathrm{N}$ mineralization. These rates for $\mathrm{N}$ mineralization are within the range of values previously shown for Treasure Valley soils and may underestimate $\mathrm{N}$ mineralization since available $\mathrm{N}$ losses could have occurred (Carter et al., 1975; Shock et al., 1998b; Stieber et al., 1995). In a survey of 30 Treasure Valley and southern Idaho sugar beet (Beta vulgaris L.) fields, the $\mathrm{N}$ mineralized (anaerobic incubation method) in the top $0.9 \mathrm{~m}$ of soil averaged $182 \mathrm{~kg} \cdot \mathrm{ha}^{-1}$ over 3 years (Shock et al., 1998b). The mineralized $\mathrm{N}$ (anaerobic incubation method) in the top $0.6 \mathrm{~m}$ of soil in seven fields following wheat in the Treasure Valley averaged $75 \mathrm{~kg} \cdot \mathrm{ha}^{-1}$ in 1993 and 134 $\mathrm{kg} \cdot \mathrm{ha}^{-1}$ in 1994 (Stieber et al., 1995). Using

Fig. 2. Onion yield response to plant population in 2000 over all $\mathrm{N}$ rates.

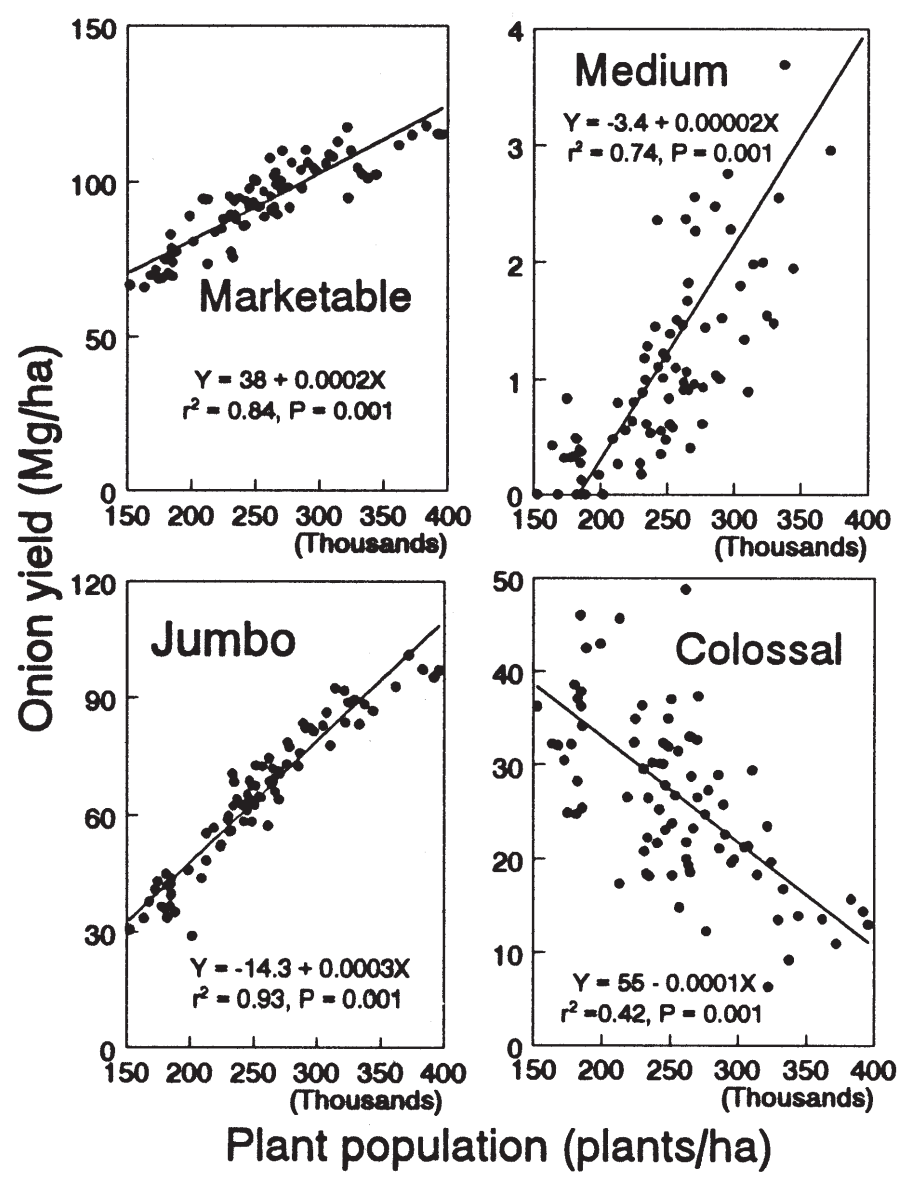

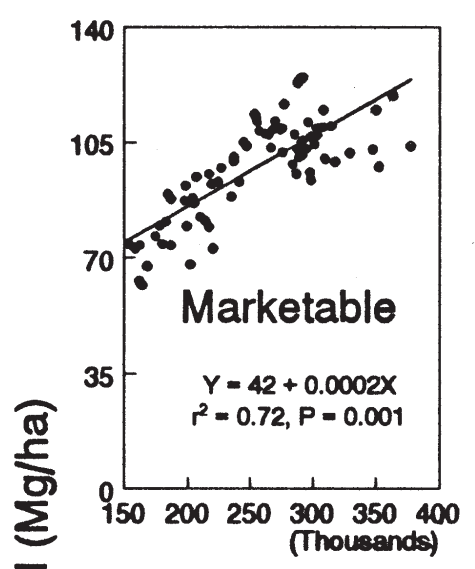
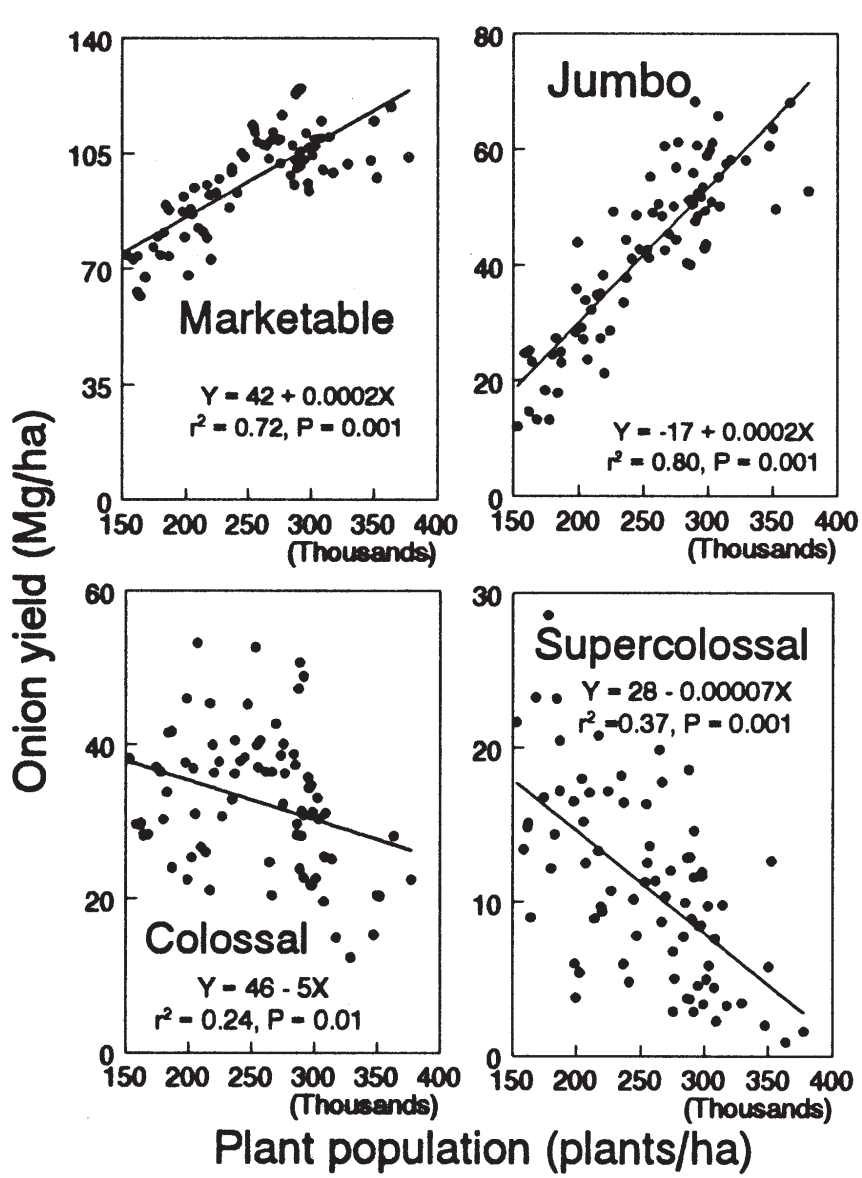
the buried bag in-field incubation method the average mineralized $\mathrm{N}$ values $\left(69 \mathrm{~kg} \cdot \mathrm{ha}^{-1}\right.$ in 1993 and $150 \mathrm{~kg} \cdot \mathrm{ha}^{-1}$ in 1994) for the same fields in Stieber et al. (1995) were close to the values determined by anaerobic incubation. Carter et al. (1975) and Shock et al. (1998b and 2000c) have shown that $\mathrm{N}$ mineralization in Treasure Valley soils can provide a large proportion of sugar beet $\mathrm{N}$ needs. The anaerobic incubation method $\mathrm{N}$ mineralization values for the fields in the current trials averaged 239, 255, and 51 $\mathrm{kg} \cdot \mathrm{ha}^{-1}$ for 1999,2000 , and 2001 respectively. $\mathrm{N}$ mineralization by anaerobic incubation provides a rapid estimate of potentially mineralizable $\mathrm{N}$ that could help growers to anticipate crop $\mathrm{N}$ fertilizer requirements.

Onion $N$ content. Plant $\mathrm{N}$ uptake did not increase with increasing $\mathrm{N}$ rate in 2000 and 2001, suggesting that $\mathrm{N}$ was not limiting and that fertilizer $\mathrm{N}$ was not needed (Table 2). Nitrogen uptake averaged $1.9 \mathrm{~kg} \cdot \mathrm{Mg}^{-1}$ of bulb fresh weight yield and is the same as the mean $\mathrm{N}$ uptake estimated for onion in the Pacific Northwest onion nutrient management guide (Sullivan et al., 2001).

Given the nonfertilizer sources of $\mathrm{N}$, the lack of onion yield response to $\mathrm{N}$ fertilizer is in agreement with the Pacific Northwest onion nutrient management guide. The fertilizer worksheet in the onion nutrient management guide calculates the amount of $\mathrm{N}$ fertilizer needed for an onion crop based on the yield goal, and takes into account the residual available soil $\mathrm{N}, \mathrm{N}$ in

Fig. 3. Onion yield response to plant population in 2001 over all $\mathrm{N}$ rates. irrigation water, and expected $\mathrm{N}$ mineralization. Using the worksheet, $\mathrm{N}$ fertilizer would not have been necessary in any of the 3 years of this trial. The lack of predicted and actual response to $\mathrm{N}$ fertilization has important implications for Treasure valley growers, especially those using drip irrigation, because of the potential to use a drip system to carefully match water applications to crop consumptive use.

Irrigation system performance. The automated irrigation system kept the soil moisture relatively constant during the season. Soil water potential at $0.2-\mathrm{m}$ depth remained close to $-20 \mathrm{kPa}$ (Fig. 6), except for brief periods due to technical problems with the automated irrigation system in 1999 and 2001. Soil water potential at a $0.46-\mathrm{m}$ depth also remained close to soil water potential at a $0.2-\mathrm{m}$ depth. Water applications over time closely followed onion ET (Fig. 7). Estimated onion ET for the 1999, 2000, and 2001 seasons totaled 729, 830, and $815 \mathrm{~mm}$, respectively. Irrigation based on soil water criteria plus precipitation totaled 635 , 814, and $963 \mathrm{~mm}$ for the 1999, 2000, and 2001 seasons, respectively.

Despite the carefully managed irrigations, volatile losses of $\mathrm{N}$ and or leaching of nitrate below the crop root zone is suggested by the negative soil $\mathrm{N}$ balances at the higher rates of applied N (Table 2). In 2000, the fall soil available $\mathrm{N}$ tended to increase with increasing $\mathrm{N}$ rate up to $226 \mathrm{~kg} \cdot \mathrm{ha}^{-1}$ applied $\mathrm{N}$ and the $\mathrm{N}$ balances were not significantly different between $\mathrm{N}$ rates. In 1999 and 2001, fall-available N was not affected by $\mathrm{N}$ rate, suggesting progressively

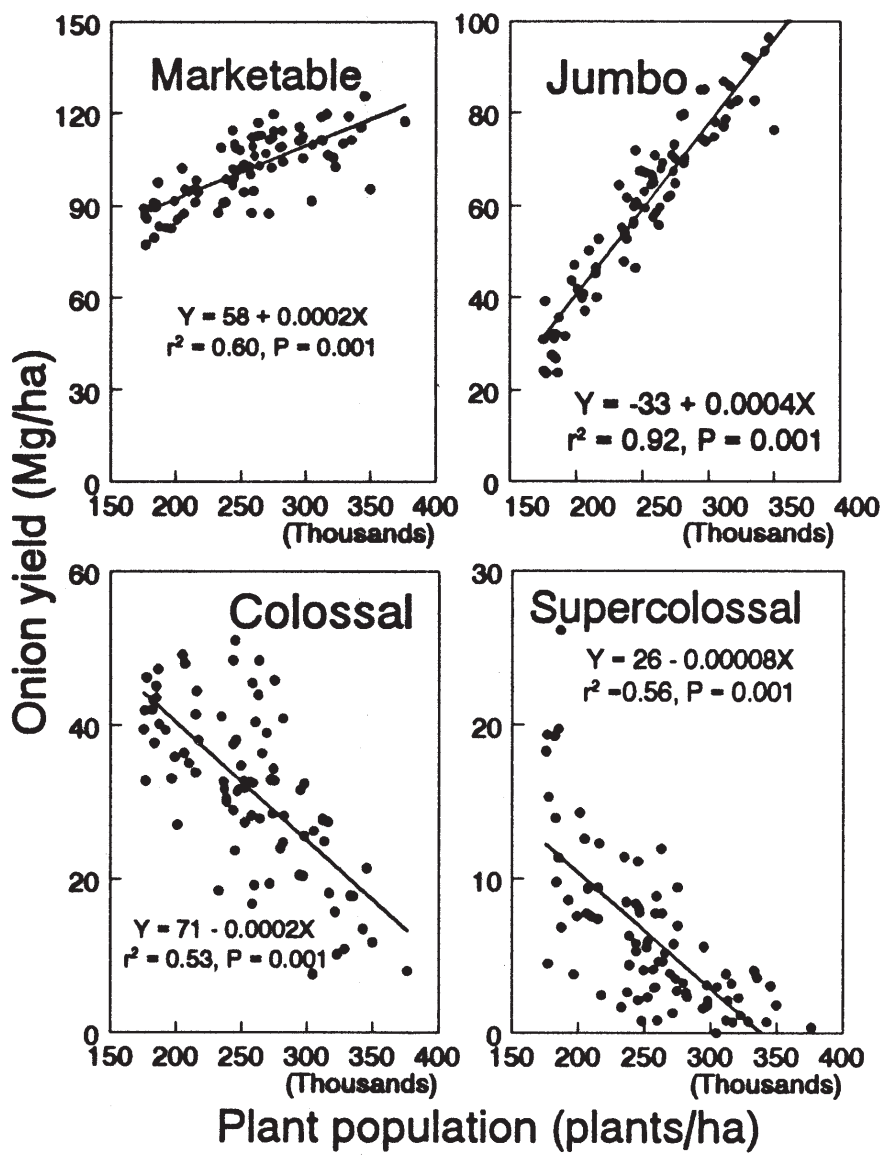

larger $\mathrm{N}$ losses with greater amounts of applied $\mathrm{N}$. The apparent large losses of $\mathrm{N}$ with added $\mathrm{N}$ above plant requirements has important financial and environmental implications for Treasure Valley growers. Nitrate is apt to be leached in these circumstances.

Water application efficiencies (ratio of $\mathrm{ET}_{\mathrm{c}}$ to irrigation water plus precipitation) were $1.15,1.02$, and 0.85 in 1999,2000 , and 2001, respectively. Some leaching would be expected because of inefficiencies and disuniformities of the drip-irrigation system. Because the drip tape was located in the bed center and $0.28 \mathrm{~m}$ from the onion double row and from the soil moisture sensors, some water might be lost to deep percolation. This inefficiency will vary from field to field with the unsaturated hydraulic conductivity of the particular soil and the degree of disuniformity of the irrigation system. All irrigation systems in arid regions require some leaching fraction to avoid salt accumulation. Installing one drip tape for each onion double row (two tapes per bed) could increase the irrigation efficiency, but would increase the drip system cost. Onion growers in the Treasure Valley typically install one drip tape for every two double rows. In the Columbia Basin of Washington and Oregon it is common to use one drip tape per three rows and three tapes per bed.

Other research, with highly efficient dripirrigation systems, has also found that some Fig. 4. Onion gross return response to plant popula-
tion over all $\mathrm{N}$ rates.

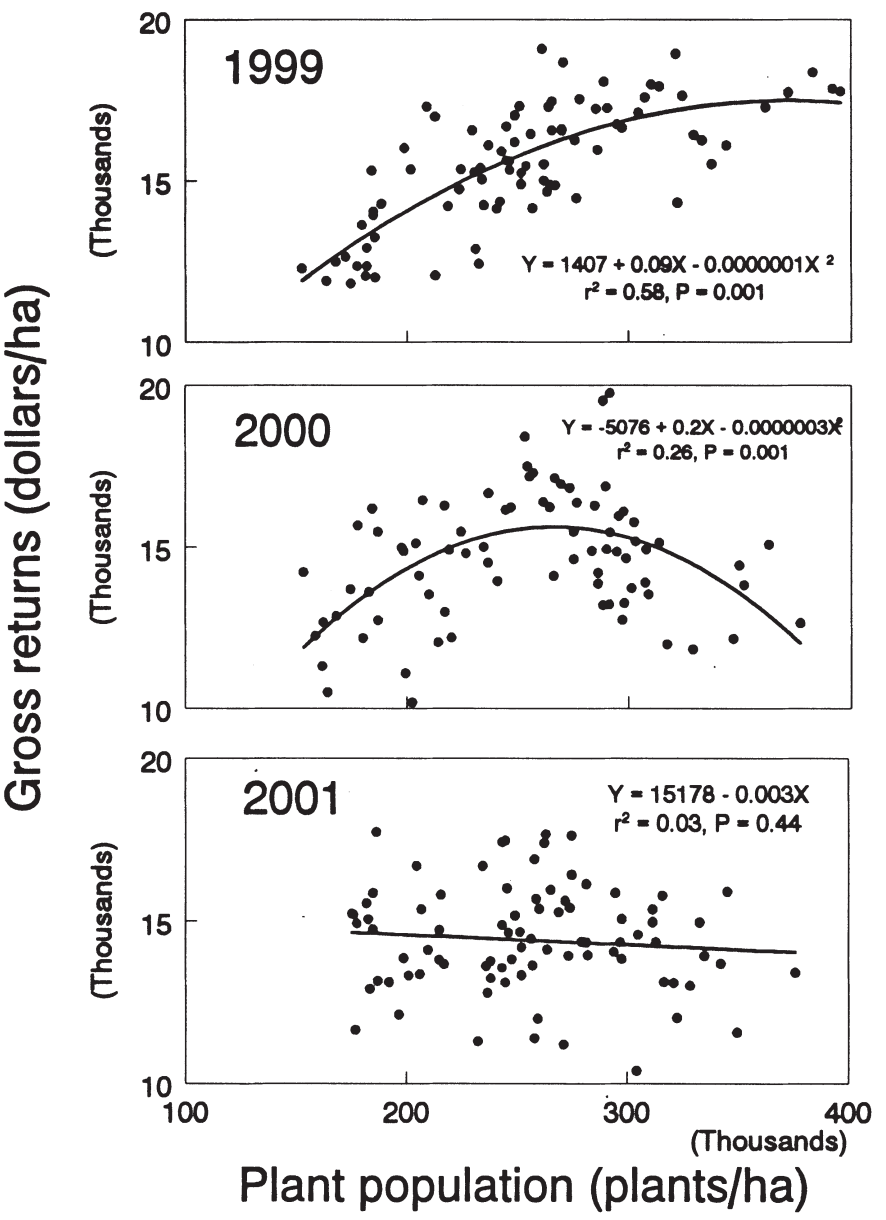




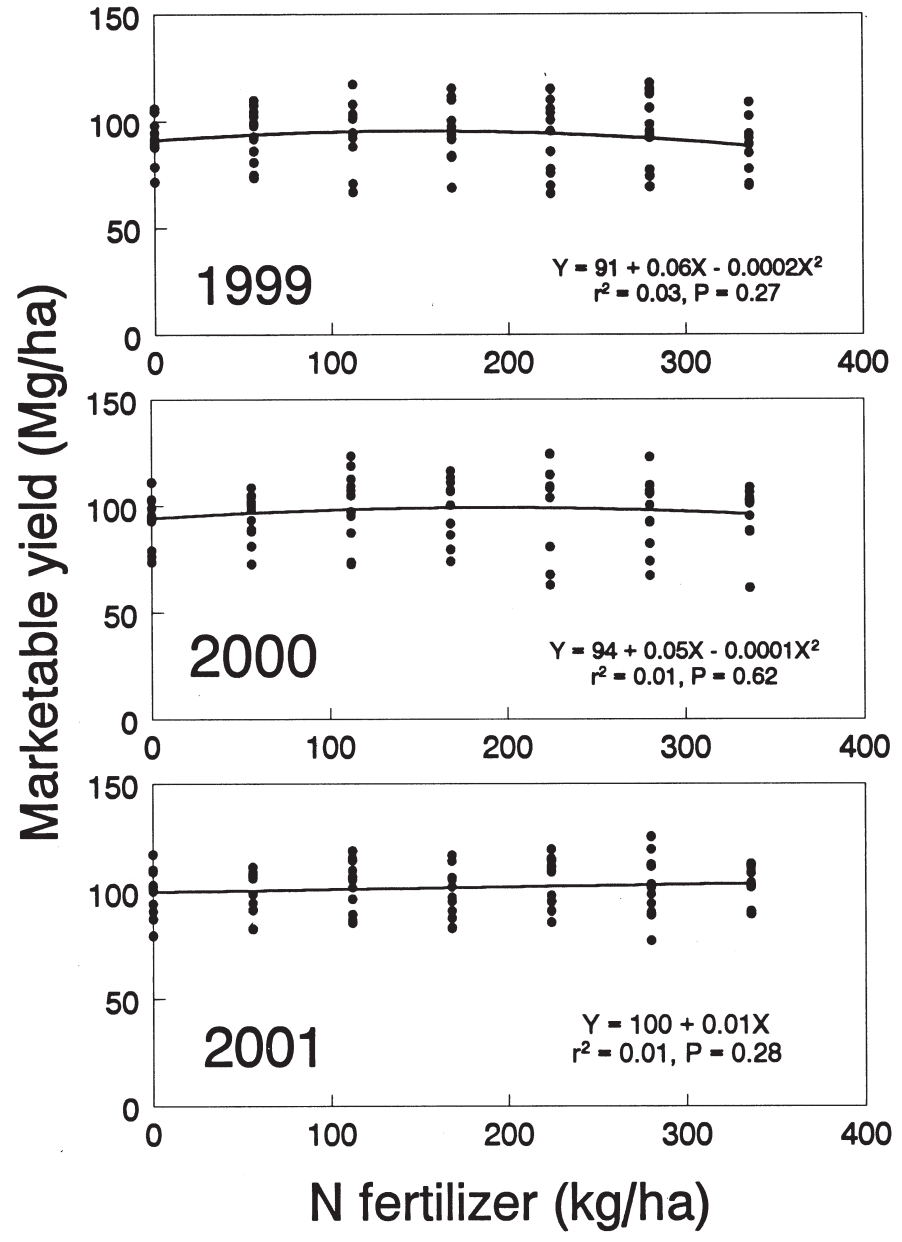

Fig. 5. Marketable onion yield response to $\mathrm{N}$ fertilizer over all plant populations.

Arizona, irrigating for maximum yield was just below or at the soil water potential that resulted

Table 2. Nitrogen budget $\left(\mathrm{kg} \cdot \mathrm{ha}^{-1}\right)$ for the upper $0.6 \mathrm{~m}$ of soil for drip-irrigated onion with seven fertilizer $\mathrm{N}$ rates $\left(\mathrm{kg} \cdot \mathrm{ha}^{-1}\right)$

\begin{tabular}{|c|c|c|c|c|c|c|c|}
\hline \multicolumn{4}{|c|}{ N supply } & \multirow{2}{*}{\multicolumn{3}{|c|}{ Fall $\mathrm{N}$ accounting }} & \multirow{3}{*}{$\begin{array}{c}\text { Difference } \\
\text { between } \\
\mathrm{N} \text { supply } \\
\text { and fall } \mathrm{N} \\
\text { accounting }\end{array}$} \\
\hline \multicolumn{3}{|c|}{$\mathrm{N}$ in } & & & & & \\
\hline $\begin{array}{l}\text { Preplant soil } \\
\mathrm{NO}_{3}+\mathrm{NH}_{4}-\mathrm{N}\end{array}$ & $\begin{array}{c}\text { Fertilizer } \\
\text { N }\end{array}$ & $\begin{array}{l}\text { irrigation } \\
\text { water }\end{array}$ & Total & $\begin{array}{c}\mathrm{N} \\
\text { uptake }\end{array}$ & $\begin{array}{c}\text { Fall soil } \\
\mathrm{NO}_{3}+\mathrm{NH}_{4}-\mathrm{N}\end{array}$ & $\begin{array}{c}\text { Accounted } \\
\mathrm{N}\end{array}$ & \\
\hline \multicolumn{8}{|l|}{$\begin{array}{l}3 \\
1999\end{array}$} \\
\hline 89 & 0 & 23 & 112 & 194 & 85 & 279 & 167 \\
\hline 89 & 56 & 23 & 168 & 197 & 100 & 296 & 128 \\
\hline 89 & 112 & 23 & 224 & 206 & 102 & 308 & 84 \\
\hline 89 & 168 & 23 & 280 & 212 & 135 & 347 & 67 \\
\hline 89 & 224 & 23 & 336 & 200 & 98 & 298 & -38 \\
\hline 89 & 280 & 23 & 392 & 212 & 93 & 305 & -87 \\
\hline 89 & 336 & 23 & 448 & 189 & 122 & 311 & -137 \\
\hline $\operatorname{LSD}_{(0.05)}$ & & & & NS & NS & NS & 43 \\
\hline \multicolumn{8}{|l|}{2000} \\
\hline 135 & 0 & 26 & 161 & 198 & 133 & 331 & 170 \\
\hline 135 & 56 & 26 & 217 & 194 & 197 & 390 & 173 \\
\hline 135 & 112 & 26 & 273 & 235 & 218 & 453 & 180 \\
\hline 135 & 168 & 26 & 329 & 207 & 322 & 530 & 201 \\
\hline 135 & 224 & 26 & 385 & 240 & 351 & 591 & 206 \\
\hline 135 & 280 & 26 & 441 & 248 & 311 & 559 & 118 \\
\hline 135 & 336 & 26 & 497 & 243 & 327 & 570 & 73 \\
\hline $\operatorname{LSD}_{(0.05)}$ & & & & NS & 102 & 111 & NS \\
\hline \multicolumn{8}{|l|}{$2001^{(0.05)}$} \\
\hline 191 & 0 & 39 & 230 & 200 & 100 & 300 & 70 \\
\hline 191 & 56 & 39 & 286 & 207 & 91 & 298 & 12 \\
\hline 191 & 112 & 39 & 342 & 239 & 119 & 358 & 16 \\
\hline 191 & 168 & 39 & 398 & 207 & 95 & 302 & -96 \\
\hline 191 & 224 & 39 & 454 & 233 & 110 & 342 & -112 \\
\hline 191 & 280 & 39 & 510 & 212 & 151 & 362 & -148 \\
\hline 191 & 336 & 39 & 566 & 201 & 148 & 349 & -217 \\
\hline $\operatorname{LSD}_{(0.05)}$ & & & & NS & NS & NS & 60 \\
\hline
\end{tabular}

in N leaching. Sweet corn (Zea mays L.) grown on sandy loam in Israel with one tape per row and irrigated daily using ET replacement, resulted in drainage below the crop root zone even with $0.25-\mathrm{L} \cdot \mathrm{h}^{-1}$ emitters (Assouline et al., 2002). The drip tape emitters used in this study had a flow rate of $0.50 \mathrm{~L} \cdot \mathrm{h}^{-1}$. However, $\mathrm{N}$ leaching was negligible for potato grown with one drip tape per row on sandy loam in Minnesota and irrigated when the soil water potential in the root zone became lower than $-30 \mathrm{kPa}$ (Waddell et al., 2000). Potatoes grown on sandy loam in South Carolina with one drip tape per row and irrigated multiple times daily to keep soil water potential above $-20 \mathrm{kPa}$, resulted in a season irrigation deficit of $14 \mathrm{~cm}$ (Phene and Sanders, 1976).

Nitrogen could also have been lost through denitrification, because of the large volume of soil that could have been under favorable conditions for denitrification. The soil water potential in the beds would range from -20 $\mathrm{kPa}$ (approximately field capacity) under the onion row to wetter in the bed center close to the drip tape.

\section{Conclusions}

Onion bulb size distribution was shown to be extremely sensitive to plant population. The introduction of a new onion size class (super colossal) has lowered the plant population that brings the highest gross returns.

Drip-irrigated onion grown in the Treasure Valley can have all or a large part of their $\mathrm{N}$ requirements met by non fertilizer sources. Before deciding on a $\mathrm{N}$ fertilization program, growers should carefully estimate the $\mathrm{N}$ supplying capacity of their soils taking into account residual soil nitrate and ammonium, $\mathrm{N}$ content of irrigation water, plus expected $\mathrm{N}$ mineralization during the growing season. In 2 of 3 years, $\mathrm{N}$ applied in excess of plant uptake could not be accounted for at the end of the growing season, suggesting losses to the environment.

\section{Literature Cited}

Al-Jamal, M.S., S. Ball, and T.W. Sammis. 2001. Comparison of sprinkler, trickle and furrow irrigation efficiencies for onion production. Agr. Water Mgt. 46:253-266.

Anon. 1991. Northern Malheur County groundwater management action plan. Malheur Co. Groundwater Mgt. Comm., Ore. Dept. Environ. Qual., Salem.

Assouline, S., S. Cohen, D. Meerbach, T. Harodi, and M. Rosner. 2002. Microdrip irrigation of field crops: Effect on yield, water uptake, and drainage in sweet corn. Soil Sci. Soc. Amer. J. 66:228-235.

Bruch, G. 1986. Pesticide and nitrate contamination of ground water near Ontario, Oregon. Impacts on Groundwater Conference, Proc. Amer. Water Well Assn. 11-13 Aug. 1986, Omaha, Neb.

Carlson, R.M. 1978. Automatic separation and conductimetric determination of ammonium and dissolved carbon dioxide. Anal. Chem. 50:1528-1531.

Carlson, R.M. 1986. Continuous flow reduction of nitrate to ammonia with granular zinc. Anal. Chem. 58:1590-1591.

Carter, J.N., D.T. Westermann, M.E. Jensen, and S.M. Bosma. 1975. Predicting nitrogen fertilizer 


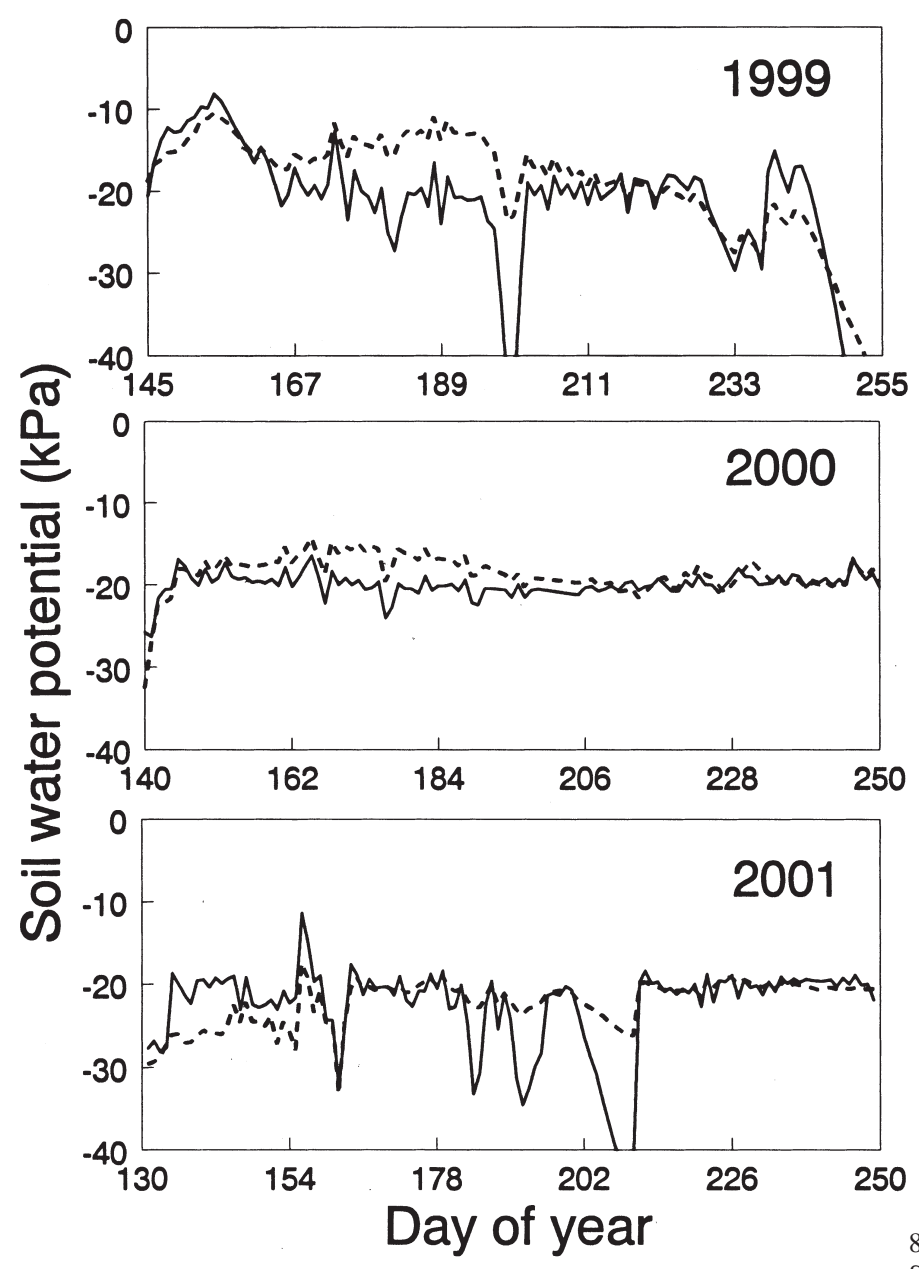

Fig. 6. Soil water potential at a $0.2-\mathrm{m}$ depth (solid line) and at a 0.46-m depth (dashed line) for onions drip-irrigated at a soil water potential of $-20 \mathrm{kPa}$.

needs for sugar beets from residual nitrate and mineralizable nitrogen. J. Amer. Soc. Sugar Beet Technol. 18:232-244.

Jensen, L.B. and B.C. Simko. 1991. Malheur County crop survey of nitrogen and water use practices. Ore. State Univ. Spec. Rpt. 882:187-198.

Miller, J.G., C.C. Shock, T.D. Stieber, and L.D. Saunders. 1992. Efficiency of nitrogen fertilization on onions 1991 trials. Ore. State Univ. Spec. Rpt. 899:75-86.

Phene, C.J. and D.C. Sanders. 1976. High-frequency trickle irrigation and row spacing effects on yield and quality of potatoes. Agron. J. 68:602-607.

Pier, J.W. and T.A. Doerge. 1995. Nitrogen and water interactions in trickle-irrigated watermelon. Soil Sci. Soc. Amer. J. 59:145-150.

Shock, C.C., T.D. Stieber, C.A. Stanger, and J.K. Ishida. 1990. Onion plant density, row spacing, and maturity group effects on bulb yield and market grade. Ore. State Univ. Spec. Rpt. 862:56-68.

Shock, C.C. and T.D. Stieber. 1991. Nitrogen uptake and removal by selected crops. Ore. State Univ. Spec. Rpt. 882:182-186.

Shock, C.C., T.D, Stieber, J.G. Miller, and L.D. Saunders. 1991.Improved nitrogen fertilizer efficiency for onion production. Ore. State Univ. Spec. Rpt. Diego, Calif. HortScience 35:63-66. 1048:61-63.

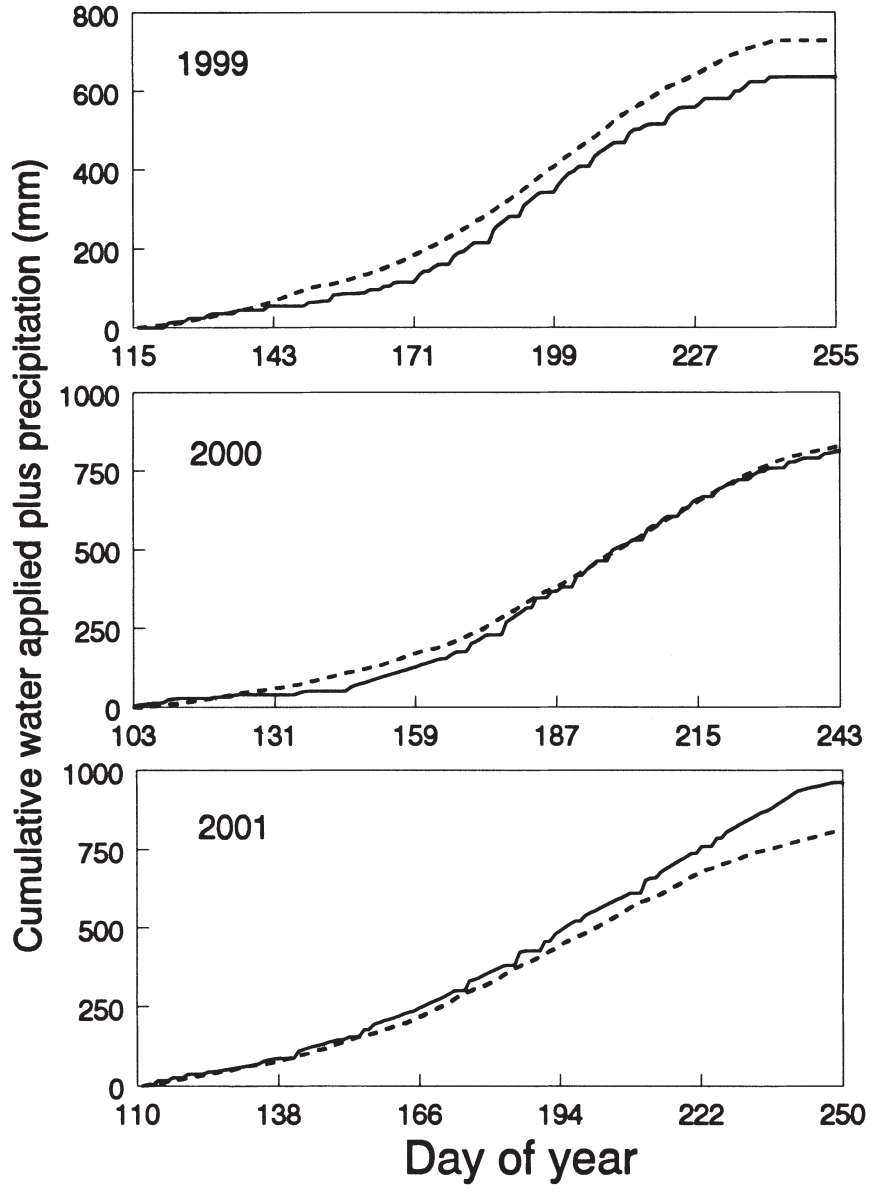

882:66-74.

Shock, C.C., J.M. Barnum, and M. Seddigh. 1998a. Calibration of Watermark Soil Moisture Sensors for irrigation management, p. 139-146. In:Proceedings of the International Irrigation Show. Irr. Assn., San

Shock, C.C., E.B.G. Feibert, and D.T. Westermann. 1998b. "On farm" implementation of lower nitrogen fertilizer inputs through nitrogen accounting and validation of organic matter mineralization. Oregon State Univ. Spec. Rpt. 988:126-134.

Shock, C.C., E.B.G. Feibert, and L.D. Saunders. 2000a. Irrigation criteria for drip-irrigated onions.

Shock, C.C., J.K. Ishida, E.P. Eldredge, and L.D. Saunders. 2000b. Yield of yellow onion cultivars in eastern Oregon and southwestern Idaho. HortTechnology 10:613-620.

Shock,C.C., M. Seddigh, L.D. Saunders, T.D. Stieber, and J.G. Miller. 2000c. Sugarbeet nitrogen uptake and performance following heavily fertilized onion. Agron. J. 92:10-15.

Shock, C.C., 2003. Soil water potential measurement by granular matrix sensors, p. 899-903. In: B.A. Stewart and T.A. Howell (eds.). The encyclopedia of water science. Marcel Dekker., New York.

Shock, C.C. and J. Klauzer. 2003. Growers conserve nitrogen fertilizer on drip-irrigated onion. Ore. State Univ. Agr. Expt. Sta. Spec. Rpt.

Stieber, T.D., C.C. Shock, E. Feibert, M. Thornton, B. Brown, W. Cook, M.M. Seyedbagheri, and D. Westermann. 1995. Nitrogen mineralization
Fig. 7. Cumulative water applied plus precipitation (solid line) and $\mathrm{ET}_{\mathrm{c}}$ (dashed line) for onion dripirrigated at a soil water potential of $-20 \mathrm{kPa}$.

in Treasure Valley soils, 1993 and 1994 results. Ore. State Univ. Spec. Rpt. 947:194-207.

Sullivan, D.M., B.D. Brown, C.C. Shock, D.A. Horneck, R.G. Stevens, G.Q. Pelter, and E.B.G. Feibert. 2001. Nutrient management for onions in the Pacific Northwest. Pacific N.W. Ext. Publ. 546

Thompson, T.L. and T.A. Doerge. 1995a. Nitrogen and water rates for subsurface trickle-irrigated romain lettuce. Hortscience 30:1233-1237.

Thompson, T.L. and T.A. Doerge. 1995b. Nitrogen and water rates for subsurface trickle-irrigated collard, mustard, and spinach. Hortscience 30:1382-1387.

Thompson, T.L., T.A. Doerge, and R.E. Godin. 2000. Nitrogen and water interactions in subsurface dripirrigated cauliflower: II. Agronomic, economic, and environmental outcomes. Soil Sci. Soc. Amer. J. 64:412-418.

Waddell, J.T., S.C. Gupta, J.F. Moncrief, C.J. Rosen, and D.D. Steele. 2000. Irrigation and nitrogenmanagement impacts on nitrate leaching under potato. J. Environ. Qual. 29:251-261.

Waring, S.A. and J.M. Bremner. 1964. Ammonium production in soil under waterlogged conditions as an index of nitrogen availability. Nature (London) 201:951-952.

Wright, J.L. 1982. New evapotranspiration crop coefficients. J. Irr. Drain. Div. ASCE 108:57-74. 